\title{
JNVEST]GHACJÓN
}

\section{Microbiological quality of karın butter, a traditionally manufactured butter from Turkey}

\author{
By Ramazan Gökçe, ${ }^{a}$ Yeşim Aslanalp, ${ }^{b}$ and Emine Nur Herken ${ }^{a}{ }^{*}$ \\ ${ }^{a}$ Pamukkale University, Engineering Faculty, Food Engineering Department, Kınıklı/Denizli, Turkey. \\ ${ }^{\mathrm{b}}$ Food Engineer (M.Sc.), Denizli Province Control Laboratory, Turkey. \\ ( ${ }^{\star}$ Corresponding author: nurherken @ pau.edu.tr)
}

\section{RESUMEN}

Calidad microbiógica de la mantequilla Karin, una mantequilla manufacturada tradicionalmente en Turquía.

La mantequilla Karin, que se caracteriza por ser envasada en el rumen (karin) de oveja o cabra, es un tipo de mantequilla tradicional. El karin, usado como un material de envasado en la produción de la mantequilla, es un importante factor para que la mantequilla sea mas aromática y deliciosa. En este estudio, muestras de mantequilla karin, que se recogieron del mercado local y de las factorias de producción, fueron investigadas con respectos las bacteria mesófilas aeróbicas, bacterias coliforme, Staphilococcus aureus y mohos-levaduras. Los resultados fueron evaluados con respecto a los acuerdos legales de Turquía y otros estudios científicos relacionados con el tema. La calidad microbiológica de las muestras de mantequilla karin fue encontrada pobre en general.

PALABRAS CLAVE: Análisis microbiológico - Karin (rumen) - Mantequilla - Mantequilla karin.

\section{SUMMARY}

Microbiological quality of karın butter, a traditionally manufactured butter from Turkey.

Karın butter, which is characterized by being packaged into sheep or goat rumen (karın), is a traditional butter type. Karın used as a packaging material in the butter production and is an important factor for the butter to be more aromatic and delicious. In this study, karın butter samples collected from factories and local markets were investigated for total aerobic mesophilic bacteria, coliform bacteria, Staphilococcus aureus and mould-yeast counts. The results were evaluated with respect to the legal stipulations of Turkey and other scientific studies related to the subject. The microbiological quality of karın butter samples was found to be poor in general.

KEY-WORDS: Butter - Karın butter - Karın (rumen) Microbiological analysis.

\section{INTRODUCTION}

Karın butter (Figure 1,2) is a kind of butter that is filled into sheep or goat rumen after being obtained from cream or churned yoghurt. The fact that the butter packaged in this way is more aromatic than butters packed in a common way is affirmed by consumers. Karın butter, which is produced and consumed in Turkey, especially in the Aydın and Denizli (in the West of Anatolia) provinces, is a kind of butter preferred in these provinces as a traditional product.

In the production of karın butter, the rumen (karın) should be prepeared first. For this aim, sheep or goat rumen is seperated from the esophagus entrance and omasum exit. The reticulum is also removed. This means that only the rumen part is used. The contents of the seperated rumen are discharged and the rumen is washed well. In the meantime, fats, lymph nodules and veins are seperated as far as possible. The rumens are stored in cold storage for a day after being turned insideout and salted with course salt. After this period,

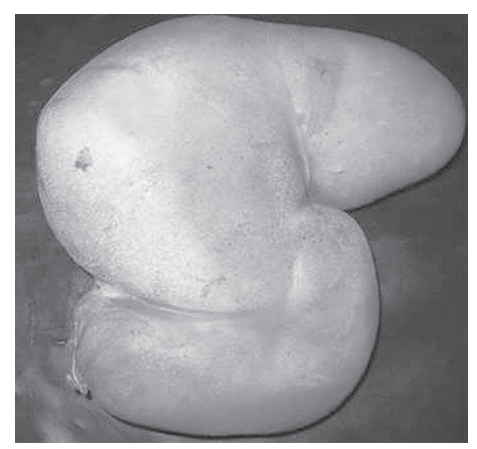

Figure 1

A picture of ready to sale karın butter as a whole. 
the serosa and mukosa layers of the rumens are seperated carefully to obtain only the muscle tissue. The rumens are then filled with air and hung to dry. The inner and outer parts of the dried rumens are resalted and folded carefully so as not to cause any cracking and stored in cold storage.

The rumen is softened with warm water and the butter ready for filling is filled in the rumen. Filling should be done carefully so that there should be no airspace nor should the rumen be torn. The filled rumen is closed tightly and stored in cold storage at $6-10{ }^{\circ} \mathrm{C}$ to mature.

Karın butter is generally produced from cream though butters obtained by churning cream or yoghurt are also used. For this aim, creams containing 70 to $80 \%$ fat are kneaded in a vessel with handles to remove any components except for fat. During the kneading process, the brine formed is discharged from the system by a discharging canal at the bottom of the vessel. After the brine is removed from the structure to a certain ratio, the butter in the vessel is washed with tap water at $18-20^{\circ} \mathrm{C}$. The butter is salted so that the final product contains $2 \%$ salt after being washed at least three times until the brine becomes clear. Kneading is continued for some time to obtain a homogenized dispersion of the salt. When the kneading operation is complete, the butter is left in cold storage for a night in blocks of $10 \mathrm{kgs}$. The next day, the butter is kneaded again to seperate the water remaining in the structure as far as possible, to homogenzse the added salt and to obtain a certain consistency for the filling operation. Water in the structure is removed by passing the kneaded butter through a spiral press before filling. The butter seperated from its water is carefully filled into the moistened karın without allowing any air pockets to form.

The butter filled into karın (rumen) is put on the market after it is stored in cold storage $\left(6-10^{\circ} \mathrm{C}\right)$ for at least 15 days. The storage period of karın butter does not usually exceed 3 months.

Karın butter is highly stable against microbial spoilage even after $2 \%$ salt addition, because of its high fat ratio, low moisture and nitrogen ratio and $12.5 \%$ soluble salt concentration. Microorganisms having lipolytic activity are highly responsible for disorders such as rancidity or loss of flavor.

The primary spoilage factors in butter are moulds and mostly greenish colored moulds are seen, but red, black and brown colored ones are also seen in butter. The majority of the moulds growing in butter are composed of the species of Thamnidium,

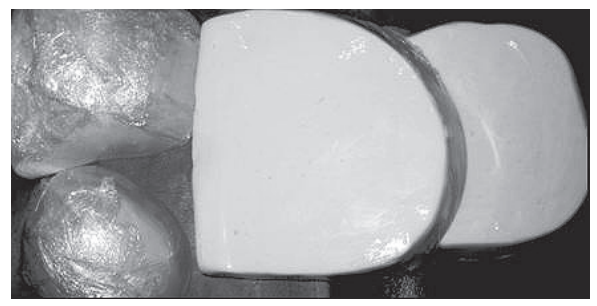

Figure 2

A picture of ready to sale and sliced karın butter.
Cladosporium and Aspergillus. Through the application of a proper heat treatment, moulds cannot survive in cream even if contamination exists. So, the presence of mould contamination in butter indicates contamination by water or air after production. The protective effect of salt added to butter cannot be underestimated in terms of moulds (Çon, 1990; Atamer, 1993). In one study (Rady and Badr, 2003), shelf life of butter was increased at $4 \pm 1{ }^{\circ} \mathrm{C}$ for 8 and 12 weeks as compared to 4 weeks for non irradiated butter (based on the visual appearance of mold growth on the surface of samples) without any effects on its sensory properties.

Coliforms as a hygiene indicator besides moulds, Staphilococcus as an important mastitis factor, total aerobic mesophilic germ number as a general higenic quality factor are important criteria for the determination of the microbiological quality of butter.

There are some studies published on the microbiological quality of traditional butters from other countries (Gonfa et al., 2001; Kacem and Karam, 2006) but this is the first study on the microbioligical assessment of karın butter which is a traditional type of butter consumed for many years in Turkey. In this study, the total aerobic mesophilic bacteria, coliform bacteria, $S$. aureus and mould-yeast counts of karın butter samples were determined and discussed on the basis of the legal stipulations of Turkey and the other scientific studies related to the subject.

\section{MATERIALS AND METHODS}

In this study, 40 karın butter samples in all which were collected from both markets and producers were studied. For this purpose, 8 samples were bought randomly from local markets notwithstanding their producers and 8 ready for sale samples $(8 \times 4=32)$ were collected from each of the 4 karın butter producers working in a high capacity located in the Denizli city province.

Samples that were no less than $250 \mathrm{~g}$ were properly collected and brought to the laboratory in less than 2 hours and microbiological analyses were made in 6 hours. Total aerobic mesophilic germ and Staphilococcus aureus counts were determined according to Karapınar (1995) and coliform microorganism and mould-yeast counts were determined according to Anonymous (1995).

The results are presented as mean values. Data were tested using SPSS for Windows Release 10 (SPSS Inc.). Statistical analysis of the results was based on One-Way Anova with Tukey tests. Statistically significant differences were considered at levels over $\mathrm{P}=0.05$ otherwise given.

\section{RESULTS AND DISCUSSION}

Total aerobic mesophilic germ counts of the samples are displayed in Table 1. Germ counts were in the range of $5.0 \times 10^{3}$ to $4.4 \times 10^{6} \mathrm{cfu} / \mathrm{g}$. There was no significant difference in the total 
Table 1

Total aerobic mesophilic germ counts (cfu/g)

\begin{tabular}{ccccccc}
\hline $\begin{array}{c}\text { Total aerobic mesophilic } \\
\text { germ count }\end{array}$ & $\begin{array}{c}\text { Producer } \\
\text { A }\end{array}$ & $\begin{array}{c}\text { Producer } \\
\text { B }\end{array}$ & $\begin{array}{c}\text { Producer } \\
\text { C }\end{array}$ & $\begin{array}{c}\text { Producer } \\
\text { D }\end{array}$ & $\begin{array}{c}\text { Market } \\
\text { Samples }\end{array}$ & Mean \\
\hline Minimum & $1.0 \times 10^{5}$ & $1.7 \times 10^{5}$ & $3.0 \times 10^{4}$ & $5.0 \times 10^{3}$ & $5.6 \times 10^{4}$ & $1.0 \times 10^{5}$ \\
Maximum & $4.4 \times 10^{6}$ & $1.5 \times 10^{6}$ & $3.7 \times 10^{5}$ & $1.6 \times 10^{6}$ & $1.4 \times 10^{6}$ & $4.4 \times 10^{6}$ \\
Mean* $^{*}$ & $1.2 \times 10^{6}$ & $5.3 \times 10^{5}$ & $1.4 \times 10^{5}$ & $4.6 \times 10^{5}$ & $4.4 \times 10^{5}$ & $5.6 \times 10^{5}$ \\
& $\pm 1.3 \times 10^{6 a}$ & $\pm 4.2 \times 10^{5 a}$ & $\pm 1.2 \times 10^{5 a}$ & $\pm 7.2 \times 10^{5 a}$ & $\pm 4.6 \times 10^{5 a}$ & $\pm 7.9 \times 10^{5 a}$ \\
\hline
\end{tabular}

${ }^{*}$ Values are expressed as mean \pm standard deviation. Means with the same letter are not significantly different $(P>0.05)$.

aerobic mesophilic germ counts of the samples obtained from the producers $(P>0.05)$.

In The Turkish Food Regulation (Anonymous, 1982), in TS 1331 Butter Standard (Anonymous, 1995) and in Turkish Food Codex Microbiological Criteria Notification (Anonymous, 2001) there is no restriction for the total aerobic mesophilic germ counts of butter. So, the results could not be assesed in this respect.

Inal (1990) classified butter with respect to its total aerobic mesophilic germ as very good quality $\left(<1.0 \times 10^{6} \mathrm{cfu} / \mathrm{g}\right)$, good quality $\left(1.0 \times 10^{6}-\right.$ $\left.2.0 \times 10^{6} \mathrm{cfu} / \mathrm{g}\right)$ and low quality $\left(>2.0 \times 10^{6} \mathrm{cfu} / \mathrm{g}\right)$. According to this classification, $80 \%$ of the butter samples were found to be very good quality, $17.5 \%$ of them were of good quality and $2.5 \%$ of them were of low quality.

In a study made in Burdur, Gün (2003) observed the total mesophilic germ numbers of karın butter samples as between $1.4 \times 10^{2}-1.0 \times 10^{7} \mathrm{cfu} / \mathrm{g}$ and the mean value as $7.5 \times 10^{5} \pm 2.6 \times 10^{6} \mathrm{cfu} / \mathrm{g}$. The results of our study are very similar to those of this study.

Hocalar (1997) concluded that for a high quality butter, the total mesophilic aerobic germ number should not exceed $5.0 \times 10^{3} \mathrm{cfu} / \mathrm{g}$. None but one of the butters in his study satisfied this condition. In those samples, such a high level of total aerobic mesophilic germ count might have been caused by various factors including the karın. In this sence, rumen is extremely rich in microflora (Tajima et al., 1999) and considerable amounts of these organisms do not lose their vitality by the process of washing and salting alone. In addition, the cream used in butter preparation might not have had a standard quality, and processing conditions might not have been be good enough so that the total aerobic mesophilic germ counts were affected.

Except for one sample, Staphilococcus aureus was not found in the samples at levels over $10^{-1}$ $\mathrm{cfu} / \mathrm{g}$. Most strains of $S$. aureus cause intoxication by producing enterotoxins that have high toxicity and are effective in intestines other than tissue toxins (Tunail 2000). In addition, it can ause meningitis, septicemia and wound infections in humans. $S$. aureus can exist in milk as an important mastitis factor and therefore can also exist in milk products that are not sufficiently heat treated (Akın, 2005).

According to the results of the analysis, $S$. aureus was not found in the samples obtained from the producers of $A, B, C$ and from market. Only one of the samples obtained from the producer $D$ was found to contain $S$. aureus at levels over $2.0 \times 10^{3} \mathrm{cfu} / \mathrm{g}$.

The Turkish Food Regulation (Anonymous, 1982), and TS 1331 Butter Standard (Anonymous, 1995) do not contain any criteria concerning $S$. aureus. However, in The Turkish Food Regulation, in the 80th article of part XII of section II it is stated that butter must not contain pathogene microorganisms. In the Turkish Food Codex Microbiological Criteria Notification (Anonymous, 2001) the maximum $S$. aureus count permitted in butter is declared as $1.0 \times 10^{2} \mathrm{cfu} / \mathrm{g}$. According to this notification, except for one sample (2.5\%), our karın butter samples $(97.5 \%)$ fulfilled this requirement. Because of this low percentage, contamination is not likely to come from the use of karın as a packaging material but may be due to a lack of hygiene in processin or to raw material of low quality.

$S$. aureus can naturally exist in raw milk, and because it can be destroyed by pasteurization easily, it should not exist in properly heat-treated milk products. $S$. aureus can be found in the milks that are not sufficiently pasteurized or that are exposed to carelessly working staff after pasteurization (Konar and Hayaloğlu, 1999; Demirel and Karapınar 2000). Because the karın butter samples used in the study are from an unpasteurized group, for the sample found to contain $S$. aureus, it is difficult to estimate at which stage it was contaminated.

The existence of coliform group microorganisms in food materials is of utmost importance because it implicates that the food product is exposed to an unsufficient heat treatment or is recontaminated afterwards. For this reason, determination of coliform group microorganisms in karın butters are of importance and the results are given in Table 2. Only 8 out of 40 samples were found to have coliform bacteria in the range of $5.0 \times 10^{1}$ to $6.3 \times 10^{2} \mathrm{cfu} / \mathrm{g}$. For the rest of the samples, it could not be found at levels over $10^{-1} \mathrm{cfu} / \mathrm{g}$.

In The Turkish Food Regulation (Anonymous, 1982) the maximum number of coliform bacteria that can be in pasteurized butter is restricted to $1.0 \times 10^{1} \mathrm{cfu} / \mathrm{g}$ and for unpasteurized butters, no value is given. In TS 1331 Butter Standard (Anonymous, 1995), in pasteurized butters, the limit for coliform bacteria is reported as $1.0 \times 10^{1}$ $\mathrm{cfu} / \mathrm{g}$ and in unpasteurized butters it is designated 
Table 2

Coliform-Group counts (cfu/g)

\begin{tabular}{lllllll}
\hline $\begin{array}{r}\text { Coliform } \\
\text { number }\end{array}$ & \multicolumn{1}{c}{$\begin{array}{c}\text { Producer } \\
\text { A }\end{array}$} & \multicolumn{1}{c}{$\begin{array}{c}\text { Producer } \\
\mathbf{B}\end{array}$} & \multicolumn{1}{c}{$\begin{array}{c}\text { Producer } \\
\mathbf{C}\end{array}$} & $\begin{array}{c}\text { Producer } \\
\mathbf{D}\end{array}$ & \multicolumn{1}{c}{$\begin{array}{c}\text { Market } \\
\text { Samples }\end{array}$} & \multicolumn{1}{c}{ Mean } \\
\hline The lowest & Not found at & Not found at & Not found at & Not found at & Not found at & Not found at \\
& $10^{-1}$ level & $10^{-1}$ level & $10^{-1}$ level & $10^{-1}$ level & $10^{-1}$ level & $10^{-1}$ level \\
The highest & $6.3 \times 10^{2}$ & $5.0 \times 10^{2}$ & Not found at & $2.0 \times 10^{2}$ & Not found at & $6.3 \times 10^{2}$ \\
& $1.2 \times 10^{2}$ & $6.3 \times 10^{1}$ & $10^{-1}$ level & $6.8 \times 10^{1}$ & $10^{-1}$ level & $5.0 \times 10^{1}$ \\
Mean* & $\pm 2.1 \times 10^{2 a}$ & $\pm 1.8 \times 10^{2 a}$ & Not found at & $\pm 9.3 \times 10^{1 a}$ & Not found at & $\pm 1.3 \times 10^{2}$ \\
& & & $10^{-1}$ level & & $10^{-1}$ level & \\
\hline
\end{tabular}

*Values are expressed as mean \pm standard deviation. Means with the same letter are not significantly different $(\mathrm{P}>0.05)$.

as $1.0 \times 10^{2} \mathrm{cfu} / \mathrm{g}$. In Turkish Food Codex Microbiological Criteria Notification (Anonymous, 2001), the limit value for coliform bacteria is reported as $9.0 \mathrm{cfu} / \mathrm{g}$ without stating that it is pasteurized or not. When TS 1331 Butter Standard and Turkish Food Codex Microbiological Criteria Notification are taken into consideration, while $80 \%$ of the samples studied are seen to satisfy the criteria given, $20 \%$ of them are not.

In a study that was carried out by Gün (2003), the coliform count was found between $2.0 \times 10^{1}-4.2 \times 10^{2} \mathrm{cfu} / \mathrm{g}$ in karın butter samples produced in Burdur. These results have similarities with the results of our samples.

Sağdıç et al. (2004) did not find coliform group microorganisms at levels over $10^{-1} \mathrm{cfu} / \mathrm{g}$ in a study made on yayık butter.

In another study that is made on pasteurized butters, Yenipazar (1997) stored the butters at temperatures of $-16 \pm 2{ }^{\circ} \mathrm{C}, 4 \pm 2{ }^{\circ} \mathrm{C}$ and $11 \pm 2{ }^{\circ} \mathrm{C}$ for 6 months and found coliform bacteria in certain intervals and coliform bacteria were not observed at levels over $10^{-1} \mathrm{cfu} / \mathrm{g}$. These studies are important because they confirm that coliforms are not risk factors for butters that are pasteurized correctly and hygienic rules are complied with. When it is taken into account that even our samples, which were not pasteurised, $80 \%$ of them carry out the legal provision; coliform bacteria should not be seen as a serious problem; but for the remaining $20 \%$ to also fulfill the requirements, attention should be paid to hygienic quality.

Mould and yeasts grow faster than bacteria and cause spoilage in food having low water activity. Besides spoilage, mycotoxin risk also exists and the determination of high amounts of mould and yeast assessed as an indicator of incorrect processing and packaging.
Some moulds and yeasts cause unwanted changes in butter. Geotrichum candidum which is known as milk mould results in a yeast smell in butter and after a time it causes a repellent taste and aroma. In the case of contamination with either Penicillium, Aspergillus, Mucor, Candida, Cladosporium, Fusarium, Rizopus, Torula or Geotrichum, spots form on the surface and mouldy taste develops in butter. Mucor stolonifer cause lipolytic and proteolytic decomposition in butter, and Candida lipolitica also causes a caustic and cheese-like taste by exerting lipolytic activity in butter (İnal, 1990; Çon and Gökalp, 1998; Konar and Hayaloğlu, 1999).

Mould and yeast counts are given in Table 3 . Mould yeast counts of the samples were found between $1.0 \times 10^{2}-2.0 \times 10^{5} \mathrm{cfu} / \mathrm{g}$, and the mean value was calculated as $4.0 \times 10^{4} \pm 5.4 \times 10^{4}$ $\mathrm{cfu} / \mathrm{g}$.

In The Turkish Food Regulation (Anonymous, 1982) the maximum number of mould yeast is stated as $5.0 \times 10^{1} \mathrm{cfu} / \mathrm{g}$ and no restriction is given for butter that is not pasteurized. In TS 1331 Butter Standard (Anonymous, 1995), mould yeast count limits are stablished as $3.0 \times 10^{1}, 6.0 \times 10^{1}$, and $1.0 \times 10^{2} \mathrm{cfu} / \mathrm{g}$ for $1 \mathrm{st}, 2 \mathrm{nd}$ and 3rd Class Kitchen Butters respectively. In Turkish Food Codex Microbiological Criteria Notification (Anonymous, 2001), the maximum value for mould yeast count is reported as $1.0 \times 10^{2} \mathrm{cfu} / \mathrm{g}$ without giving any class number and without stating that it is pasteurized or not. Because the samples used in this study are not pasteurized, the results were evaluated according to unpasteurized butter values of TS 1331 Butter Standard and limit values given in Microbiological Criteria Notification; and it is determined that while $12.5 \%$ of the samples satisfy the given criteria, $87.5 \%$ of them do not. Producers buying their raw

Table 3

Mould-yeast counts (cfu/g)

\begin{tabular}{lcccccc}
\hline $\begin{array}{c}\text { Mould-yeast } \\
\text { counts }\end{array}$ & $\begin{array}{c}\text { Producer } \\
\text { A }\end{array}$ & $\begin{array}{c}\text { Producer } \\
\text { B }\end{array}$ & $\begin{array}{c}\text { Producer } \\
\text { C }\end{array}$ & $\begin{array}{c}\text { Producer } \\
\text { D }\end{array}$ & $\begin{array}{c}\text { Market } \\
\text { Samples }\end{array}$ & Mean \\
\hline The lowest & $1.5 \times 10^{4}$ & $1.0 \times 10^{3}$ & $1.0 \times 10^{2}$ & $1.0 \times 102$ & $6.0 \times 10^{3}$ & $1.0 \times 10^{3}$ \\
The highest & $2.1 \times 10^{5}$ & $3.4 \times 10^{4}$ & $1.7 \times 10^{5}$ & $1.10 \times 10^{5}$ & $1.5 \times 10^{5}$ & $3.4 \times 10^{4}$ \\
Mean* $^{*}$ & $8.5 \times 10^{4}$ & $9.0 \times 10^{3}$ & $2.3 \times 104$ & $4.0 \times 10^{4}$ & $4.4 \times 104$ & $4.0 \times 10^{4}$ \\
& $\pm 7.2 \times 10^{4 a}$ & $\pm 1.0 \times 10^{4 a}$ & $\pm 6.0 \times 10^{4 a}$ & $\pm 4.1 \times 10^{4 a}$ & $\pm 4.5 \times 10^{4 a}$ & $\pm 5.4 \times 10^{4}$ \\
\hline
\end{tabular}

${ }^{*}$ Values are expressed as mean \pm standard deviation. Means with the same letter are not significantly different $(\mathrm{P}>0.05)$. 
material from various places and defining criterion in buying these goods should be aware of the high mould-yeast count values. Moreover, other factors such as poor hygienic conditions and personel not showing sensitivity to hygiene may prevail on this result.

In the study of Gün (2003) carried out in Burdur, mould-yeast count was found as $1.0 \times 10^{1}-9.7 \times 10^{3} \mathrm{cfu} / \mathrm{g}$. When these results are compared, it is noteworthy that mould-yeast numbers of the samples produced in Denizli are reported higher than those of the samples produced in Burdur. This result is thought to be related to the quality of cream as a raw material of butter and the hygienic quality of butter production conditions.

\section{CONCLUSION}

In this study, the microbiological quality of the karın butters that are produced in Denizli were examined and results show that it was unsatisfactory. Cream bought from various places without setting a criteron, insufficient hygenic conditions of the production plants, improper handling procedures and the rumen itself used as a packaging material are posibble factors that play a role in this result. In the case of an improvement in these conditions, karın butter, which is a traditional product, can be presented better therefore be a product that is consumed by a wider range of people. In addition, more research should be done on traditional products, as they have not been sufficiently studied.

\section{REFERENCES}

Akın N. 2005. Çiğ Süt Kalitesi ve Süt İşletmelerinde Hijyen Prosedürleri. AB Sürecinde Kaliteli Süt Üretimi ve Somatik Hücre Sayısı, Konya Ticaret Borsası Yayını 60-76s. Konya (Turkish).

Anonymous 1982. Gıda Maddelerinin ve Umumi Sağlığı Illgilendiren Eşya ve Levazımın Hususi Vasıflarını Gösteren Tüzük, 35-40 s., Titiz Ofset Matbaası, Ankara (Turkish).

Anonymous 1995. TS 1331 Tereyağı Standardı, Türk Standartları Enstitüsü, Ankara (Turkish).

Anonymous, 2001. Türk Gıda Kodeksi Mikrobiyolojik Kriterler Tebliği, TC Resmi Gazete, Başbakanlık Basımevi, Ankara (Turkish).
Atamer M, 1993. Tereyağı Teknolojisi Uygulama Klavuzu. A.Ü. Ziraat Fakültesi, Ankara, 9-40 (Turkish).

Çon AH. 1990. Samsun Piyasasında Satışa Sunulan Tereyağlarının Bazı Nitelikleri Üzerine Bir Araştırma. Master's thesis, Food Engineering, University of Ondokuz Mayıs, Samsun.

Çon AH, Gökalp HY. 1998. Gıda Mikrobiyolojisi Ders Notları, PAÜ Mühendislik Fakültesi Basım Ünitesi, Denizli (Turkish).

Demirel N, Karapınar M. 2000. Süt ürünlerinde Staphilococcus aureus. Süt Mikrobiyolojisi ve Katkı Maddeleri. VI. Süt ve Süt Ürünleri Sempozyumu Tebliğler Kitabı, İzmir, 78-85 (Turkish).

Gonfa A, Foster HA, Holzapfel WH. 2001. Field survey and literature review on traditional fermented milk products of Ethiopia. International Journal of Food Microbiology 68, 173-186.

Gün İ. 2003. Some quality characteristics and production technology of karın fats produced in Burdur. SDÜ, Journal of Graduate School of Natural and Applied Sciences 7, 55-58.

Hocalar BT. 1997. Tereyağı Teknolojisi. Ege Üniversitesi, EMYO, İzmir, 3-89 (Turkish).

İnal T. 1990. Süt ve Süt Ürünleri Hijyen ve Teknolojisi. Final Ofset AŞ, İstanbul, 579-685 (Turkish).

Kacem M, Karam NE. 2006. Physicochemical and microbiological study of "shmen", a traditional butter made from camel milk in the sahara (Algeria):isolation and identification of lactic acid bacteria and yeasts. Grasas y Aceites 57, 198-204.

Karapınar M. 1995. Gıdaların Mikrobiyolojik Kalite Kontrolü. Ege Üniversitesi, EMYO, İzmir, 30-57 (Turkish).

Konar A, Hayaloğlu A. 1999. Tereyağı Üretim Yöntemleri, Krema ve Yoğurttan Elde edilen Tereyağlarının Fizikokimyasal, Mikrobiyolojik ve Duyusal Nitelikleri. Standard, Ankara 448, 83-85 (Turkish).

Rady AH, Badr HM. 2003. Keeping the quality of cows' butter by g-irradiation. Grasas y Aceites 54, 410-418.

Sağdıç O, Dönmez M, Demirci M. 2004. Comparison of caracteristicsand fatty acid profiles of traditional Turkısh yayik butters produced from goats, ewes or cows milk. Food Control 15, 485-490.

Tajima KR, Aminov I, Nagamine T, Ogata K, Nakamura M, Matsui H, Benno Y. 1999. Rumen bacterial diversity as determined by sequence analysis of $16 \mathrm{~S}$ rDNA libraries. FEMS Microbiol. Ecol. 29, 159-169.

Tunail N. 2000. Gıda Mikrobiyolojisi ve Uygulamaları. A.Ü. Ziraat Fakültesi Gıda Mühendisliği Bölümü Yayınları, 300-350s. Ankara (Turkish).

Recibido: $15 / 7 / 09$ Aceptado: 16/9/09 